test was carried out on the 7th and 8th passaged stock with anti-Echo 23 monkey serum ${ }^{3}$. The test consisted essentially of mixing equal volumes of every dilution of virus in phosphate-buffered saline $\left(10^{-1}\right.$ $\left.10^{-6}\right)$ with every dilution of uninactivated serum (1 : 1,024-1:256,000) in phosphate-buffered saline. The mixtures were incubated in a $37^{\circ} \mathrm{C}$ water bath for $1 \mathrm{~h}$. $0 \cdot 1 \mathrm{ml}$. of each mixture was then inoculated into each set of six tubes devoid of growth medium and washed with phosphate-buffered saline. This was followed $15-20$ min later with 1.5 c.c. of Sabin's maintenance medium. Incubation of the test was at $37^{\circ} \mathrm{C}$ and tubes were examined microscopically for cytopathogenicity daily for seven days.

The cytopathic lesions of Echo 23 are typified in the early phase by rounded or ovoid cells in grape-like clusters and with clear cytoplasm and refractilo edges usually at the periphery of the cell sheet. As more virus is produced the whole periphery of the cell sheet shows this typical degeneration, and occasionally similar clusters of rounded cells are found in the centre of the cell sheet. The cytopathic effect usually begins 24-36 h after infection. Cellular destruction is usually not complete. Table 1. Final DaY (7) REAding OF AN Optimal Dilutron NeU-
TRALIZATION TEST WITH Echo 23 IN MONKEX KIDNEY TISSUE

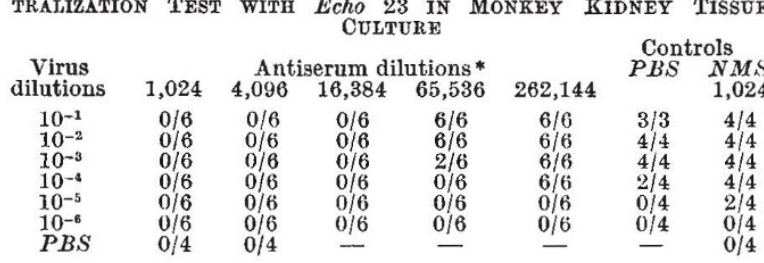

Inoculum $0 \cdot 1$ c.c. of virus-serum mixture.

* Reciprocals of dilutions.

Numerator, No. showing cytopathic effect; denominator, total tubes per dilution mixture.

NMS, Normal monkey serum; PBS, phosphate-buffered saline.

The results of a typical optimal dilution neutralization test with this virus are shown in Table 1. By this method it has been possible to determine the $T C D_{50}$ of the virus and the neutralizing titre of the serum without first resorting to a separate titration test for the virus, and then determining the neutralizing titre of serum in another test. Conventional neutralization test on Echo 23 using the same serum as above and $100 T C D_{50}$ virus gave an $S D E$ of I : 65,536. So far we have been able to maintain serial passages (11 passages) of Echo 23 in monkey kidney tissue culture without loss in infectivity.

The Echo virus (Williamson) was kindly supplied by Dr. Albert B. Sabin.

This work was supported in part by a U.S. Public Health Service research grant $C-6006$, from the National Institutes of Health.

Akinyele Fabiyi

LELIA M. OLSEN

JeAN WESTON

Herbert A. Wenner

Section for Virus Research,

Department of Pediatrics,

University of Kansas

School of Medicine,

Kansas City.

'Wigand, R., and Sabin, A. B., Arch. Virusforsch., 9, 226 (1961). 2 Shaver, D. N., Barron, A. L., and Karzon, D. 'T., Proc. Soc. Exp. Biol. Med., 106, 648 (1961)

${ }^{3}$ Kamitsuka, P., Soergel, M. E., and Wenner, H. A., Amer. J. Hyg., 74, 7 (1961).

\section{Monkey Pox Disease in Irradiated Cynomologous Monkeys}

A POX-LIKE infection was observed in a female cynomologous monkey $(B-39)$ approximately 45 days following exposure to whole-body irradiation of $350 \mathrm{r}$. Monkey $B-39$ had been maintained in the same area for approximately ten months and was one of the eight survivors of a group of monkeys used in a series of irradiation studies. All were apparently free from any noticeable infection until the appearance of the pox lesions. Similar pox lesions were seen in one other irradiated monkey $(B-44)$ in an adjacent cage a few days later.

Clinical lesions similar to those described by von Magnus et al. ${ }^{1}$ and Prier and Saucr ${ }^{2}$ were observed. These lesions included pox-like skin eruptions, severe facial and cervical œdema, hæmorrhagic ulcerations, dyspncea, and bloody diarrhœa. Both infected monkeys died twelve days following the outbreak of the disease. Only one non-irradiated monkey (C-302) became infected with the agent. This monkey had cervical œdema and ulcerated areas on the arms and forehoad similar to the lesions seen in the other two animals ( $B-39$ and $B-44)$; however, this animal survived the infection. No signs of infection were seen in the remaining survivors of the irradiation study, nor in the 19 other non-irradiated monkeys that were housed in the samo room.

Virus isolation was attempted from seabs obtained from the thigh area of monkoy $B-39$. An agont which produced a cytopathogenic effect in monolayers of monkey kidney epithelial cells was isolated. Transmissibility was established by serial passage of the isolate in monkey kidney tissue culture and in rabbit kidney tissue eulture. The appearance of a typical cytopathogenic effect (Figs. 1 and 2) was used as the criterion for virus multiplication. First, monkey

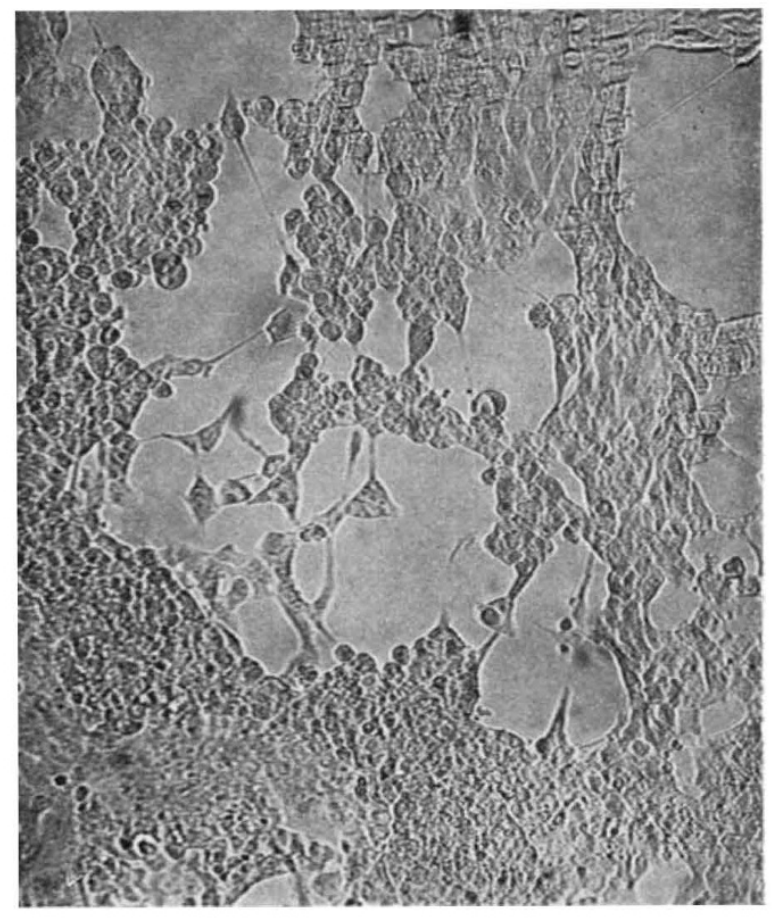

Fig. 1. Cell destruction in monkey kidney epithelial cells infeeted with "monkey pox agent" four days post infection. ( $\times 104)$ 


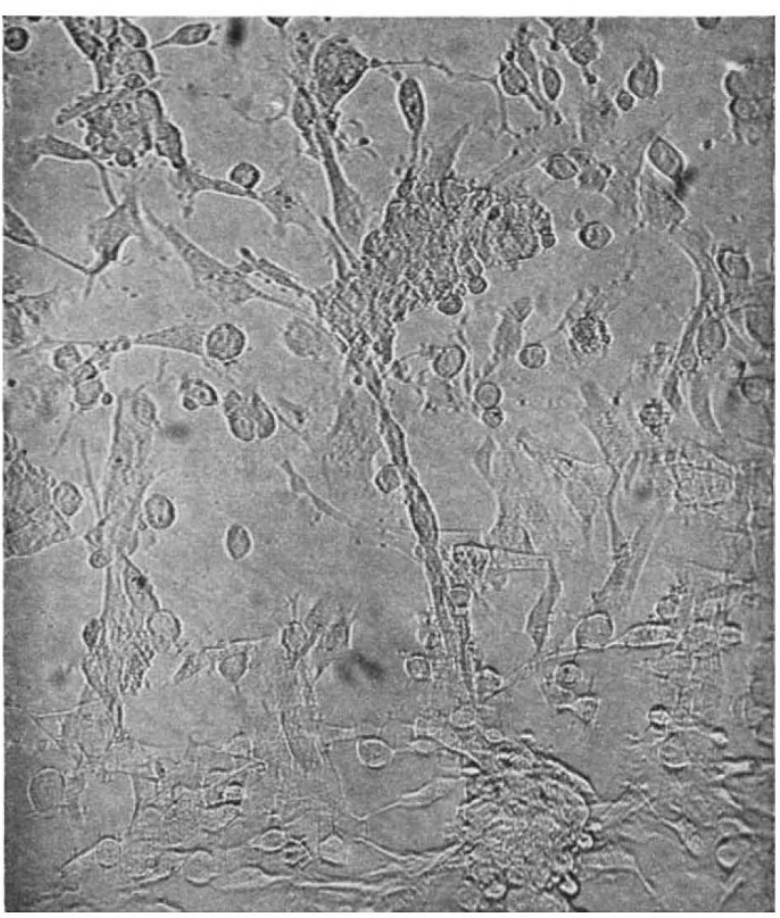

Fig. 2. Cell destruction in rabbit kidney epithelial cells infected with 'monkey pox agent', flve days post infection. ( $x$ 104)

kidney tissue fluid containing the isolate when inoculated on the chorioallantoic membrane of 13-day-old embryonated eggs produced lesions with considerable necrosis and hæmorrhage. A 20 per cent suspension of the infected membranes in physiological saline solution hæmagglutinated susceptible chicken red blood cells with a titre of 1 : 128. Two hæmagglutinating units of antigen were inhibited by $1: 640$ dilution of hyperimmune vaccinia rabbit serum which had been adsorbed with chick red blood cells. The agent was then classed as a member of the variolavaccinia group. This agent was not neutralized in tissue culture by herpes $B$ (Herpes simae) hyperimmune serum.

Animal inoculation techniques differentiated the isolate from variola. Death resulted in 3-week-old mice when inoculated intracranially, but not when inoculated intraperitoneally as reported previously by Prier et $a l .^{3}$. The agent was successfully passed serially in the epidermis of adult rabbits, thus differentiating it from variola 4

A serological survey of our monkey colony was conducted at this time to determine the number of monkeys with detectable hæmagglutination-inhibition antibody to the isolated agent. The results aro given in Table 1.

The room in which the monkey pox disease occurred showed 89.3 per cent of the 28 cynomologous monkeys to have a significant hæmagglutination inhibition titre of $1: 80$ and higher. The highest hæmagglutination inhibition titres, $1: 2,560$ and $1: 1,280$, were found respectively in the serum of the non-irradiated. cage mate $(B-38)$ and in the convalescent serum of the non-irradiated infected monkey $(C-302)$. In contrast only 11 per cent of the 45 cynomologous monkeys caged in other separate rooms showed significant hæmagglutination inhibition titres. One cynomologous monkey out of this total had a high $(1: 1,280)$
Table 1. SERologrcal SURpey of MONKey Colony for Monkey

\begin{tabular}{|c|c|c|c|c|c|c|}
\hline $\begin{array}{l}\text { Species } \\
\text { of } \\
\text { monkey }\end{array}$ & $\begin{array}{l}\text { No. ex- } \\
\text { posed to } \\
\text { irradiation }\end{array}$ & $\begin{array}{l}\text { No. with } \\
\text { clinical } \\
\text { monkey } \\
\text { pox } \\
\text { disease }\end{array}$ & $\begin{array}{c}\text { Hæmagg } \\
0 \text { titre }\end{array}$ & $\begin{array}{l}\text { glutinati } \\
1: 10-- \\
1: 40\end{array}$ & $\begin{array}{l}\text { on inhib } \\
1: 80- \\
1: 640\end{array}$ & $\begin{array}{c}\text { tion titres } \\
1: 1,280 \\
\text { and } \\
\text { higher }\end{array}$ \\
\hline $\begin{array}{l}\text { Cynomo- } \\
\text { logous }\end{array}$ & $\begin{array}{l}\text { Irradiated } 8 \\
\text { Not ir- }\end{array}$ & 2 & 2 N.D. & 1 & 5 & 0 \\
\hline Cynomo- & $\begin{array}{l}\text { radiated } 22 \\
\text { Not ir- }\end{array}$ & 1 & 1 & 1 & 18 & 2 \\
\hline $\begin{array}{l}\text { logous* } \\
\text { Rhesus }\end{array}$ & $\begin{array}{l}\text { radiated } 45 \\
\text { Not ir- }\end{array}$ & 0 & 30 & 10 & 4 & 1 \\
\hline $\begin{array}{c}\text { African } \\
\text { green }\end{array}$ & $\begin{array}{l}\text { radiated } 67 \\
\text { Not ir- } \\
\text { radiated } 14\end{array}$ & 0 & 9 & 6 & 46 & 6 \\
\hline
\end{tabular}

${ }_{*}^{N}$. Monkeys not in area of occurrence of monkey pox discase.

hæmagglutination inhibition titre, while 30 were without titres and 10 had titres of $1: 40$. It is interesting to note that $\mathbf{7 7 . 5}$ per cent of the 67 rhesus monkeys had hæmagglutination inhibition titres of $1: 80$ and higher.

From the results obtained, it would appear that the monkey pox virus may be carried by some species of monkeys as a latent virus. Irradiation, by decreasing host resistance, may lead to the appearance of clinical disease. Other monkeys can then acquire the disease clinically or, more likely, sub-clinically.

\section{Stewart J. McConnelt YAYE F. HeRMAN Donald E. Mattson LEROY ERICKSON}

Departments of Veterinary Microbiology and Laboratory Animals,

Walter Reed Army Institute of Research, Washington 12, D.C.

${ }^{1}$ von Magnus, P., Andersen, E. K., Petersen, K. B., and BirchAndersen, A., Acta Pathol. Microbiol. Scand., 46, 156 (1960).

2 Prier, J. E., and Sauer, R. M., Ann. N.Y. Acad. Sci., 85, 951 (1960)

' Prier, J. E., Sauer, R. M., Malsberger, R. G., and Sillaman, J. M., Amer. J. Vet. Res., 21, 381 (1960).

- Downie, A. W., Viral and Rickettsial Infections of Man, edit. by Rivers, T. M., and Horsfall, jun., F. L. (J. P. Lippincott Co., Philadelphia, 1959).

\section{Airborne Transmission of Influenza Virus Infection in Mice}

THE mode of transmission of influenza has been the subject of great controversy ${ }^{1}$ Human volunteers can be experimentally infected by dropping infected fluids into the nasopharyn $x^{2}$, by inhalation of finely atomized liquid suspension ${ }^{3}$, or by inhalation of room air into which virus has been introduced by aerosol spray ${ }^{4}$. However, there is no direct evidence to prove whether epidemic or pandemic influenza is spread by direct contact by large droplets, or by finely dispersed airborne droplet nuclei.

Indirect evidence of airborne transmission was found by $\mathrm{McClean}^{5}$, in an examination of a hospital unit equipped with ultra-violet irradiation. The incidence of influenza was lower among patients housed in the irradiated unit than among patients housed in a non-irradiated unit.

Direct experimental evidence showing that ferrets could transmit influenza virus infection by the airborne route has been given by Andrewes and Glover 6 .

A model has been developed in this laboratory for the study of transmission of influenza virus infection in mice. Mice are infected with influenza virus by exposure to an aerosol spray of $A 2$ (Asian) virus. We 